\title{
Research Paper Smallholder farmers: Agricultural credit in India performance and challenges
}

Author for

Correspondence :

VENKATESWARLU

YERUKALA

Department of

Economics, University of

Hyderabad, HYDERABAD

(TELANGANA) INDIA

Paper History :

Received : 24.10.2016;

Revised : 22.01.2017;

Accepted : 01.02.2017
Abstract : : This paper intends to retrospect the agriculture credit policy in India since from independence. Paper particularly looks the role of different agricultural credit institutions such as, Regional Rural Banks (RRBs), National Bank for Agriculture and Rural Development (NABARD and other Scheduled Commercial Banks (SCBs) and analyses the issues and challenges in ensuring agricultural credit facility to the farmers. This paper also gives us an understanding about the importance of formal agricultural credit to the smallholder farmers for ensuring the farmers subsistence life and agricultural stability. Finally, paper compares the institutional and non- institutional credit in terms of credit accessibility, dependence and farmers welfare. The methodology of the paper is based on both primary and secondary data. Secondary data has been taken from different government organizations. The primary data has been taken from Andhra Pradesh in order understand the farmers dependence on institutional and non-institutional sources at household level.

KeY Words : Smallholder farmers, Agricultural credit, Credit institutions, Credit accessibility, Farmers welfare, JEL Code: H81, Q14, O16

How To Cite This PAper : Yerukala, Venkateswarlu (2017). Smallholder farmers: Agricultural credit in India performance and challenges. Internat. Res. J. Agric. Eco. \& Stat., 8 (1) : 88-95, DOI : 10.15740/HAS/IRJAES/8.1/ 88-95. 